University of Wollongong

Research Online

Faculty of Law - Papers (Archive)

Faculty of Business and Law

$1-1-2012$

\title{
Climate change and the oceans: legal and policy portents for the Asia Pacific region and beyond
}

Robin Warner

University of Wollongong, rwarner@uow.edu.au

Clive Schofield

University of Wollongong, clives@uow.edu.au

Follow this and additional works at: https://ro.uow.edu.au/lawpapers

Part of the Law Commons

\section{Recommended Citation}

Warner, Robin and Schofield, Clive: Climate change and the oceans: legal and policy portents for the Asia Pacific region and beyond 2012, 1-20.

https://ro.uow.edu.au/lawpapers/646

Research Online is the open access institutional repository for the University of Wollongong. For further information contact the UOW Library: research-pubs@uow.edu.au 


\title{
Climate change and the oceans: legal and policy portents for the Asia Pacific region and beyond
}

\author{
Abstract \\ The oceans dominate the globe spatially, covering approximately 72 per cent of its surface area. These \\ extensive marine spaces are critical to the global environment and human survival in numerous ways - \\ they are vital to the global nutrient cycling, represent a key repository and supporter of biological diversity \\ on a world scale, and playa fundamental role in driving the global atmospheric system. Moreover, the \\ oceans continue to provide a critical source of food through/fisheries and aquaculture, are an increasingly \\ significant source of energy resources, and underpin the global economy through sea-borne trade.

\section{Keywords} \\ policy, region, legal, oceans, change, climate, pacific, asia, portents, beyond \\ Disciplines \\ Law

\section{Publication Details} \\ R. Warner \& C. Schofield, 'Climate change and the oceans: legal and policy portents for the Asia Pacific \\ region and beyond' in $\mathrm{R}$. Warner \& C. Schofield(ed), Climate Change and the Oceans: Gauging the Legal \\ and Policy Currents in the Asia Pacific and Beyond (2012) 1-20.
}




\section{$<\mathrm{cn}>1 . \quad<\mathrm{c}>$ Climate change and the oceans: legal and policy portents for the Asia-Pacific region and beyond} $<$ au>Robin Warner and Clive Schofield

<epigraph>How inappropriate to call this planet Earth when it is quite clearly Ocean.

(Arthur C. Clarke, Nature, v. 344, p. 102)</epigraph>

$<\mathrm{a}>1$. INTRODUCTION

The oceans dominate the globe spatially, encompassing over 70 per cent of its surface area. These extensive marine spaces are critical to the global environment and human survival in numerous ways - they are vital to the global nutrient cycling, represent a key repository and supporter of biological diversity on a world scale, and play a fundamental role in driving the global atmospheric system. Moreover, the oceans continue to provide a critical source of food through fisheries and aquaculture, are an increasing source of energy resources, and underpin the global economy through sea-borne trade.

The oceans are, however, under increasing threat. In addition to well recognized threats such pollution and dumping, as well as urgent concerns over over-fishing, the destruction of valuable habitats and the preservation of marine biodiversity, the oceans have had a longstanding role as the primary sink for excess heat and carbon present in the global climate system. Consequently, the oceans have and are continuing to experience profound impacts as a consequence of climate change. In particular, substantial impacts on marine 
environments will result from increasing water temperatures, changes to the chemistry of seawater, including ocean acidification, changes in ocean circulation systems leading to shifts in the strength and direction of ocean currents, increases in the geographical range, frequency and intensity of extreme weather events, as well as potentially substantial and potentially abrupt sea-level rise.

The multidimensional impacts of climate change are likely to pose disastrous and destabilizing threats for many maritime regions with potentially dire consequences for marine and coastal environments, resources and populations. Inspired by mutual interest in one of the most important challenges of our times, this book has risen from ongoing research by the contributing editors Robin Warner and Clive Schofield into the legal and policy implications of climate change for the world's oceans. The volume draws together a range of informed opinions by leading scholars from diverse disciplines on the impacts of climate change on the oceans with a particular emphasis on the Asia-Pacific region (taken to mean the broad geographical area bordering the western Pacific Ocean including East and Southeast Asia, the Pacific Island States and Oceania), but also taking into account global developments. Legal and policy responses to those developments are explored at the global, regional and national levels, and from the perspectives of different maritime sectors. The book aims to raise awareness of the intensifying effects of climate change on the oceans and the need for proactive and balanced governance of these to mitigate adverse impacts, both globally and within the Asia-Pacific region.

This introductory chapter seeks to draw out some of the key themes explored in the volume. These are all associated with the potential and actual impacts of climate change on the oceans, notably in terms of the marine environment, living resources such as fisheries, and marine biodiversity. Impacts on the scope of maritime jurisdictional claims on the part of coastal States are outlined, and the potential impact of climate change-related impacts on the 
oceans such as sea-level rise on contentious maritime and territorial disputes are explored. The implications of such developments for maritime security present a further focus, before attention shifts to options to mitigate the impacts of climate change on the oceans.

\section{$<\mathrm{a}>2$. CLIMATE CHANGE IMPACTS ON THE OCEANS}

As the oceans absorb more of the heat generated by global warming, seawater expands and causes a rise in sea levels. Even discounting the effects of glacial and ice sheet melting, the Intergovernmental Panel on Climate Change (IPCC) has projected a global average rise in sea levels of 30-40 cm by the end of the century (IPCC 2007). It has also forecasted that a changing climate, including alterations to wind patterns and storm climatology, are likely to produce more intense tropical storms, which, in combination with sea level rise, will result in more frequent storm surges and thus more severe flooding (IPCC 2007). This will have varying effects in the Asia-Pacific region depending primarily on coastal topography. At particular risk are river deltas such as those in the South East Asian region, which over the long term will be permanently submerged or eroded away. For example, Vietnam, which possesses the major deltas of the Red River and, especially, the Mekong River, is expected to lose over 14,000 square miles of delta areas, where substantial portions of its population, as well as some of its most productive agricultural land, are concentrated. Significant delta areas are similarly disappearing in Thailand, Burma and Indonesia (CENTRA Technology, Inc. and Scitor Corporation 2010; Jasparro and Taylor 2008). The combined effects of sea-level rise, increased storm activity and changes in sea temperature and salinity will, for example, intensify already existing threats to important coastal environments such as the mangrove forests of the region, and coastal deltas in South East Asia. These areas provide crucial natural protection for the rest of the coast and their loss is likely to lead to substantial erosion. 
Additionally, mangroves offer important habitats that currently play a vital role in biodiversity preservation and, for instance, in sustaining regional fisheries upon which millions depend as their primary source of protein. Sea-level rise, flooding and storm activity will also lead to the inundation of multiple small and, critically, low-lying islands in the region, especially in the Indonesian and Philippine archipelagos, with Indonesia projected to lose 2000 small islands by 2030 (CENTRA Technology, Inc. and Scitor Corporation 2010). The threatened retreat of shorelines also poses potential knock-on effects in terms of impacts on baselines and thus the spatial scope of national claims to maritime jurisdiction. Coastal cities, towns and villages in the region will also confront the risk of inundation from sea level rise and wild weather resulting in the destruction of housing and infrastructure. Indeed, even if low-lying islands and mainland coastal areas are not entirely submerged, repeated flooding coupled with salt-water intrusion is likely to have negative implications for the continued habitability of these areas. As well as socioeconomic disruption and potential civil unrest within States of the region, the aftermath of sea-level rise and the severe weather events associated with climate change may also lead to mass displacements of people seeking shelter and economic viability beyond their own States (Barnett and Adger 2007; Smith 2007). This would add to the already high numbers of boat people moving among islands in South East Asia and to proximate countries such as Australia and New Zealand.

The rising temperature of global oceans will result in the relocation and in some cases extinction of marine species. The 2008 Report of the FAO Expert Workshop on Climate Change Implications for Fisheries and Aquaculture highlights the nature and extent of climate change impacts expected in the South China Sea and adjacent South East Asian and Pacific waters. As noted above these include higher water temperatures; sea-level rise; an increase in the frequency and intensity of storms; changes in the quantity, location and timing of rainfall; as well as changes in the effects of the El Niño Southern Oscillations weather 
factor (Food and Agriculture Organization [FAO] 2008). In particular, an increase of 0.6$0.7^{\circ}$ in water temperature is predicted for the tropical regions including the South China Sea and South East Asia, leading to increased stratification and reduced mixing of water in lakes, reduced primary productivity and ultimately reduced food supplies for fish species (WorldFish Center 2006). Higher water temperatures will result in more frequent algal blooms, less dissolved oxygen, and an increased incidence of disease and parasites, which in turn will lead to less abundant species and composition in fish stocks, as well as substantial increases in infrastructure and operating costs for aquaculture enterprises. Higher water temperatures are also forecast to affect the timing and success of fish migrations, spawning, sex ratios and peak abundance with the potential loss of shifts in composition for some species (WorldFish Center 2006). The damage and destruction to coral reefs and other marine ecosystems associated with increased ocean acidity is also likely to erode the economic security of many States in the Asia-Pacific region by removing vital fisheries habitats and sources of tourist industry income. A specific example of the effects of higher water temperatures on fish abundance is the anticipated decline in skipjack tuna in the waters of the Coral Triangle, directly to the south of the South China Sea large marine ecosystem (Willis et al. 2008).

As coral reefs and other fragile marine ecosystems degrade, processes such as environmental impact assessment and marine spatial planning, including the designation of marine protected areas in coastal zones and beyond, will become increasingly important in conserving marine living resources and biodiversity. The adverse effects of climate change on the oceans also highlight the need for coastal States, regional fisheries management organizations and regional seas organizations to adjust their conservation and management regimes in response to a changing and dwindling pool of resources and increasing threats to biodiversity. This book examines the potential patterns and locations of climate change 
effects on marine biodiversity in the Asia-Pacific region and analyses current and projected legal and policy responses to these dimensions of climate change.

Continuing sea level rise, which is already affecting the South China Sea and South East Asia, is expected to have similarly deleterious effects on fisheries and aquaculture productivity. As noted above, Vietnam is especially vulnerable and has already experienced a 2.5-3 cm increase in sea level over the last 50 years. In the Lower Mekong Basin the sea level has risen by as much as $3 \mathrm{~cm}$, with further increases predicted, possibly by as much as 1 m by the end of the century (Mekong River Commission [MRC] 2010; see also Doyle et al. 2010). The loss of land and the saltwater intrusion induced by sea level rise has resulted in damage to and loss of freshwater fisheries, and a reduced area available for land-based aquaculture (WorldFish Center 2006). The increased likelihood of severe weather events associated with climate change such as large waves and storm surges poses higher direct risks to fishers, including loss of equipment and aquaculture stock and damage to aquaculture facilities (WorldFish Center 2006). Reponses to salinity changes have prompted the building of more dykes and water gates along coastlines in the South East Asian region, fragmenting fisheries habitats and disturbing fish migration and spawning (WorldFish Center 2006; CENTRA Technology, Inc. and Scitor Corporation 2010).

The changed location and timing of ocean currents and upwelling linked to climate change is also expected to alter the nutrient supply to fish in surface waters, leading to changes in distribution and productivity of open sea fisheries (WorldFish Center 2006). A further well-documented effect of climate change and land-based pollution is the bleaching of coral reefs, resulting in reduced reef fish productivity (CENTRA Technology, Inc. and Scitor Corporation 2010). 
Rising sea levels are also likely to significantly affect the extent of coastal State claims to maritime jurisdictional zones and the valuable marine resources within them. This threat of the loss of currently claimed maritime spaces arises because of the fundamental link between the limits of maritime zones and the baselines along the coast from which such zones are measured. Most baselines are 'normal' ones coincident with the low-water line along the coast which, in turn, is vulnerable to retreat inland in the face of sea level rise. As baselines are pulled back inland, so the limits of maritime jurisdiction measured from them will likewise shift position, leading to a reduction in maritime spaces under the jurisdiction of the coastal State concerned. This problem persists even when straight or archipelagic baselines have been defined, as is the case for a number of States in the Asia-Pacific, because such straight-line type baselines still need to be tied back and anchored to normal, low water line baselines which are susceptible to change in the face of sea-level rise. Similarly, sea-level rise has the potential to lead to the inundation of small islands or, alternatively, their depopulation and change in status, with significant potential reductions in the capacity of these features to generate extensive maritime claims. Significant reductions in the scope of coastal State maritime claims inevitably has implications in terms of jurisdiction over and access to valuable marine resources, both living, such as fisheries, and non-living, including seabed hydrocarbons.

As the effects of climate change intensify, and impacts on baselines and maritime jurisdictional limits increasingly come to the fore, significant repercussions for the negotiation of maritime boundaries and resolution of disputes may arise. While boundary treaties have a privileged position in international law with a view to ensuring their permanence and inviolability, nonetheless as coastlines recede due to erosion and flooding there may be demands to reopen apparently settled boundary disputes. Moreover, the 
majority of potential maritime boundaries globally have yet to be settled and the Asia-Pacific region features multiple notable territorial and maritime disputes of long standing (Prescott and Schofield 2005). These include disputes concerning sovereignty over small islands in the East China Sea between China and Japan and multiple groups of islands in the South China Sea, including the infamous dispute over the Spratly Islands, which involves six claimants (Brunei, China/Taiwan, Malaysia, the Philippines and Vietnam). In large part though not wholly as a result of the sovereignty disputes over these small features, these semi-enclosed seas both feature broad areas of overlapping maritime claims and serious maritime boundary disputes. Additionally, notable maritime jurisdictional disputes exist in the Gulf of Thailand, particularly between Cambodia and Thailand and also in the Sulawesi (Celebes) Sea, involving Indonesia and Malaysia.

The impacts of sea-level rise on baselines, islands and maritime claims may well lead to fluctuations in the positions taken by States in maritime delimitation negotiations, complicating settlement of existing disputes as fresh arguments emerge over which baselines should be used in the construction of equidistance lines which are the frequent starting points for discussions (Caron 1990; Prescott and Schofield 2005; Paskal 2007). The inundation of islands will also potentially affect sovereignty claim over them, as well as their sovereign rights to offshore maritime resources (Freestone 1990; Schofield 2009). For example, with the onset of sea-level rise many of the Spratly Islands may be permanently submerged, potentially undermining the basis for territorial sovereignty claims based on these insular features. However, States rarely concede sovereignty over territory easily, and such disputes may persist should the claimant and occupying States undertake concerted reclamation or protection works in order to preserve the threatened, yet disputed, features. Such actions would themselves be likely to generate further frictions among the disputants. That said, the Asia-Pacific region is also host to innovative practice in respect of provisional arrangements 
of a practical nature designed to address the challenge of contentious maritime disputes and overlapping maritime claims. Examples include maritime joint development arrangements designed to facilitate exploration for seabed hydrocarbons in the Gulf of Thailand between Malaysia and Thailand and Malaysia and Vietnam, as well as joint fishing zones between China and Vietnam in the Gulf of Tonkin (Bac Bo Gulf in Vietnamese, Beibu Gulf in Chinese) in the northern South China Sea, and several joint fishing arrangements in the East China Sea (between China and Japan, China and Korea and Japan and Korea). Perhaps more urgently, as the adverse impacts of climate change deepen for many of the States of the AsiaPacific involved in maritime disputes, especially those bordering the East China Sea and South China Sea, heightened competition for dwindling resources will increase the potential for re-escalation of tensions (Schofield et al. 2011). If claimant States choose to enforce their claims using military power this could lead to more confrontations at sea (Bradford 2005).

\section{$<\mathrm{a}>4$. CLIMATE CHANGE AND MARITIME SECURITY}

Sea-level rise coupled with more severe weather events centring in the ocean - such as sea surges and violent storms - may threaten the territory of coastal States and lead to small island States becoming uninhabitable. These developments will have wide-ranging security implications for the Asia-Pacific region and beyond, potentially generating significant flows of climate change refugees affected by loss of their homes and livelihoods and prompting coastal States to review their migration and refugee laws. The trend towards greater numbers of environmental refugees transiting ocean areas in the South China Sea and South East Asia has a range of security implications for governments developing policy responses. There will be greater public pressure on governments of transit and destination States such as Malaysia, Indonesia, Australia and New Zealand to tighten border security and devote more law 
enforcement and immigration resources to the detection and processing of boat people (Barnett and Adger 2007). The higher numbers of vulnerable displaced persons will provide additional opportunities for people smuggling networks to flourish, with commensurate pressures on police and prosecution authorities to target and deal with offenders. The hazardous nature of people smuggling operations, which entail movement by sea in overcrowded and unseaworthy vessels, will also impose extra responsibilities on already overstretched regional navies and coastguards to respond to distress calls and escort people smuggling vessels to processing centres (Abbott 2008; CENTRA Technology, Inc. and Scitor Corporation 2010).

The increased frequency and severity of weather-related disasters linked to climate change is likely to lead to loss of dwellings and the spread of disease in the Asia-Pacific region and the need for augmented disaster relief services (Jasparro and Taylor 2008; CENTRA Technology, Inc. and Scitor Corporation 2010). In the face of such severe weather events, the high volumes of shipping transiting the region may become more vulnerable to accidents at sea, and offshore energy installations may be more prone to damage and less able to provide reliable sources of energy (CENTRA Technology, Inc. and Scitor Corporation 2010).

Fisheries scientists have predicted that the migration, depletion or even collapse of major fisheries as a result of rising ocean temperatures and increases in ocean acidity caused by global warming in addition to other factors such as overfishing will result in declining food security in regions that are heavily dependent on fish as a key source of protein for their populations (WorldFish Center 2006; FAO 2008; Allison et al. 2009). Indeed, the marine living resources of the Asia-Pacific are critical to the food security of coastal populations numbering in the hundreds of millions (Schofield et al. 2011). Dwindling food and energy resources may provide a catalyst for inter- and intra-State disputes in the Asia Pacific region 
leading to a less predictable and secure maritime environment for trading and military access (Abbott 2008; Dupont 2008; CENTRA Technology, Inc. and Scitor Corporation 2010). This book examines these diverse security effects, and the legal and policy initiatives being canvassed in the Asia-Pacific region to tackle the maritime security implications of climate change.

\section{$<\mathrm{a}>5$. CLIMATE CHANGE MITIGATION AND THE OCEANS}

As well as the effects of climate change itself, marine geo-engineering schemes to mitigate the adverse impacts of climate change, such as ocean fertilization, pose significant risks to the marine environment that may lead to a less productive marine environment in the long-term (Shepherd 2009). In the process of adapting to the ravages of climate change, States and their nationals are already engaging in climate change mitigation activities with potentially adverse impacts on the marine environment. Similarly, maritime-oriented sectors such as the shipping industry are themselves turning their efforts towards minimizing the impact of their activities. International organizations are just beginning to grapple with the environmental regulation of activities, such as offshore carbon capture and ocean fertilization, and many coastal States have yet to incorporate appropriate precautionary measures and environmental impact assessment processes into their domestic legislation and policy. This book reviews progress at the global, regional and national levels in developing and implementing these measures.

\section{$<$ a>6. ORGANIZATION AND CONTENT}

As well as this introductory chapter, the book contains nine chapters examining the issues surrounding climate change and the oceans from several key perspectives. Chapters 2-4 explore the physical effects of climate change on the marine environment, fish stocks and 
marine biodiversity of the Asia-Pacific region, and the legal and policy implications of these changes. Chapter 5 analyses the role of the Southern Ocean and the Antarctic region in the global climate and the broader legal and policy consequences of climate change impacts in these areas for other regions, including the Asia-Pacific region. Chapter 6 analyses the complex issues surrounding maritime jurisdiction and climate change and the conundrums this poses for presently established maritime limits and boundaries, suggesting response options open to coastal States in this context. Chapter 7 highlights the multidimensional security consequences of climate change impacts on the oceans, including increased people flows, threats to food security and loss of livelihood for many communities in the AsiaPacific region. Chapter 8 examines the ramifications of these broad security challenges for maritime security forces in the region and the potential transformations needed in force structures and postures to tackle these developments. Chapter 9 focuses on the topical issue of greenhouse gas (GHG) emissions from global shipping, and the regulatory framework being developed by the International Maritime Organization (IMO) to mitigate this significant contributor to global emissions. Finally, Chapter 10 describes the emerging array of climate change mitigation activities associated with the oceans, and global initiatives to regulate these activities. A brief synopsis of each of these chapters follows.

Chapter 2 by Ove Hoegh-Guldberg sets the scene for the chapters that follow. HoeghGuldberg explores the influences of global warming and ocean acidification on Pacific coastal and oceanic ecosystems, and the implications of these changes for the economy and well-being of people throughout the Asia-Pacific region. The importance of coastal and ocean ecosystems in underpinning the food and livelihoods of Asia-Pacific people due to the dominance of low-lying coastal areas and islands within the geography of the region is explained, as well as the highly productive nature of ecosystems such as coral reefs, mangroves and seagrass meadows. These ecosystem services include food, fisheries, building 
materials, medicine, tourist income and the indirect but important benefits derived from the stabilizing and protective function of ecosystems such as mangroves and coral reefs on coastal areas. The author also points to the benefits derived from resources within the AsiaPacific region associated with the open ocean such as tuna, which provides substantial revenue to Asia-Pacific States. Based on his discussion of future scenarios for the AsiaPacific region, Hoegh-Guldberg predicts that under the influence of global warming and ocean acidification, coral-dominated reef systems, mangroves and seagrass beds will contract by as much as 50 per cent, which will directly affect the temperature-dependent distribution of pelagic fish such as tuna. In addition there will be more frequent damaging storm systems and a rise in sea levels of around 10-15 cm. He concludes that marine ecosystems within the region will disappear if the trends towards atmospheric $\mathrm{CO}_{2}$ concentrations of $450 \mathrm{ppm}$ and global temperatures of more than $2^{\circ} \mathrm{C}$ above the pre-industrial level are not halted, and recommends the adoption of a number of strategies to address these conditions in the AsiaPacific region. The first proposal is to reduce the impact of local stresses such as overfishing, coastal land degradation and marine pollution by increasing the resilience of coastal ecosystems to climate impacts such as storm damage, mass coral bleaching and heat stress. Secondly, in the management of fisheries, the suggestion is to create evolving, dynamic and 'adaptive' frameworks capable of responding to the changing conditions, challenges and opportunities arising from the shifting physical and chemical conditions throughout the AsiaPacific region. Thirdly, greater cooperation is advocated across nations in the management of pelagic fish stocks in response to changing conditions causing the movement of fish stocks. Finally, there need sot be greater cooperation across national borders, with the establishment of regional networks of expertise and capability to respond to the enormous challenges posed by climate change. 
Richard Kenchington and Robin Warner focus on legal and policy responses to the impacts of climate change on marine biodiversity both globally and in the Asia-Pacific region in Chapter 3. They point to some of the key effects of climate change on marine biodiversity, including increasing water temperature; changes in the chemical properties of seawater; sealevel rise; increased frequency, severity and range of severe weather events; and increasing thermal and other stresses on species due to all these factors. They discuss the difficulty in separating these effects from other anthropogenic impacts such as the overexploitation of fisheries and marine resources; coastal habitat destruction; and operational and catastrophic accidental pollution arising from marine industries, shipping, and land and freshwater uses. In terms of legal and policy responses they underscore that this amalgam of impacts on marine biodiversity, including climate change effects, requires multi-sectoral integration of policy and management within jurisdictions, coordination with adjacent and linked jurisdictions, and regional and international mechanisms to address areas beyond national jurisdiction. The chapter explores some of the key approaches to conserving and managing marine biodiversity in the face of threats such as climate change. These include marine protected area tools for biodiversity conservation and habitat protection, multi-use management tools that balance conservation and socioeconomic uses, sustainable use marine-resource management tools, primarily for extractive use and culture/ecological/social protection reserves, especially for indigenous and traditional non-indigenous communities. The chapter traces the development of legal and policy frameworks for the conservation of biodiversity and their linkages with climate change effects at the global, regional and national levels. The chapter concludes that ongoing efforts to address the impacts of climate change on marine biodiversity will benefit from the development of more integrated legal and policy frameworks for the conservation and management of biodiversity across national boundaries and beyond national jurisdictions. 
In Chapter 4 Pia Winberg, Ana Rubio and Lisa Kirkendale focus on the vital need to sustain marine living resources for food production despite adverse climate change effects, examining subsistence, artisanal and global fisheries and aquaculture operations across different socioeconomic conditions in the Asia-Pacific. They point out that collectively the Asia-Pacific includes the three largest seafood-producing regions globally: the Northwest Pacific, the Southeast Pacific and the Western Central Pacific. Millions of people in both Asia and the Pacific rely on seafood production for subsistence as well as for local and export markets. They discuss the additional complexities involved in maintaining sustainable fisheries and aquaculture operations with the advent of climate change. Changes include altered marine food chains, shifting productivity, changes to the breeding patterns of commercial species and changes in their distribution - all leading to variable and erratic production. Three main categories of climate change effects - physical, chemical and ecological/biological - are substantiated and translated into a concrete suite of impacts on fisheries and aquaculture in the Asia-Pacific region. The impacts predicted include changes in production and types of yield, growth and mortality effects, species shifts, increased pests and fouling, decreases in genetic diversity, lack of feed and reduced harvest and market regularity. A range of response options to each of these impacts is considered, and the policy implications of the options are synthesized at the end of the chapter.

Chapter 5 by Marcus Haward first addresses the critical role of the Southern Ocean and Antarctica in the global and regional climate. The winter-summer seasonal pattern of sea-ice formation and loss, which more than doubles the ice-covered area of Antarctica, is discussed as a driver in the global climate system with important links to the region's ecosystem. The role of the Southern Ocean as a major store or sink of the world's carbon and as an integral part of the carbon cycle where atmospheric $\mathrm{CO}_{2}$ is absorbed by chemical and biological processes is also reviewed. The chapter then examines the regimes and instruments 
that govern the Southern Ocean, exploring the impact of climate change on the operation of these. Thus addressed are the Antarctic Treaty, the Protocol to the Antarctic Treaty on Environmental Protection and the Convention for the Conservation of Antarctic Marine Living Resources, as well as key global instruments such as the United Nations Convention on the Law of the Sea, the Convention on Biological Diversity, the United Nations Framework Convention on Climate Change (UNFCCC), and shipping instruments such as the International Convention on Prevention of Pollution from Ships (MARPOL 73/78) and the Convention and Protocol on the Prevention of Marine Pollution by Dumping of Wastes and Other Matter. Haward explains that the science-based focus of the Antarctic treaty system has been critical in supporting new research on the impacts of climate change on the Southern Ocean and the global oceans. The chapter concludes with observations on the influence of the intersection between science, law and policy in addressing climate change, drawing on the example of the Southern Ocean.

In Chapter 6 Clive Schofield and Andi Arsana explore one of the most notable impacts of climate change: sea-level rise. This phenomenon has led to concerns over the inundation of extensive low-lying coastal territories, with disastrous implications for coastal populations, infrastructure and environments. These concerns are underscored by longstanding trends towards the concentration of global population and activity in areas proximate to the coast such that an estimated 60 million people live within $1 \mathrm{~m}$ of present sea levels. Alarm has also been raised over the potential disappearance of entire islands and States entirely composed of islands, forcing island inhabitants to flee. Sea level rise also has significant potential to reduce the spatial extent of national claims to maritime jurisdictionthis maritime dimension of the impact of sea level rise provides the primary focus for discussion. The potential for losses to maritime claims because of sea-level rise emerges from the fundamental link between baselines - predominantly represented by low-water lines 
along the coast - and the limits of maritime jurisdiction zones. Further, the chapter highlights how sea-level rise is both spatially and temporally highly uneven, and notes that firm answers to the critical questions of how much and how swiftly global sea levels may rise presently remain uncertain - an issue that largely stems from the complexities inherent in measuring sea-level rise. The critical link between baselines and limits of maritime jurisdiction zones is then explored, with an emphasis on the potentially uneven ways sea-level rise could affect the extent of maritime claims. Options open to coastal States with a view to retaining their present maritime entitlements are then reviewed, with an emphasis on the various ways maritime limits can be defined and potentially stabilized.

Stuart Kaye considers in Chapter 7 how two key issues for the international community, maritime security and climatic change, are related, and why the impacts of climate change may increasingly inform the nature of responses to maritime security. He posits that greater pressure on fisheries due to climate change may exacerbate a number of maritime security issues. These include potential increases in illegal fishing and bilateral disputes over marine living resources. Consequently, some States in the Asia-Pacific region are more likely to adopt robust maritime law enforcement policies to protect precious and dwindling fish stocks in marine areas under their jurisdiction, as well as in those areas where they have potential claims to marine living resources. The obverse position is that those States in the region with limited maritime law enforcement capacity to protect their fish stocks are likely to become more vulnerable to illegal fishing. Kaye also raises the issue of intensifying pressures on populations in the Asia-Pacific region affected by sea-level rise to relocate. He foreshadows a more restrictive view being taken by developed States in the Asia Pacific region of their international law obligations to climate change refugees resorting to illegal migration by sea. In conclusion, Kaye predicts that the two issues of maritime security 
and climate change are likely to become more interlinked in the future in the Asia-Pacific region and beyond.

In Chapter 8 Chris Rahman addresses the implications of climate change for maritime security forces including navies, coastguards and other maritime law enforcement agencies such as customs. First, he considers the potential for climate change to create negative conditions for national or regional security. He highlights the negative political consequences that could arise as result of the physical impacts of climate change, such as the loss of land for dwellings and pressure on natural resources. Although such condition do not themselves necessarily lead to violent conflict requiring military intervention, he suggests that, realistically, they could lead to problems of disorder on land and sea that require humanitarian assistance and law enforcement. In the Asia-Pacific region he suggests that this is likely to result in increased illicit activities at sea such as illegal fishing, smuggling, illegal migration, piracy and sea robbery. Secondly, he analyses the future demands that will be imposed on maritime security forces as a consequence of climate change and the possible implications for force structure development. He focuses on the example of the US Navy as the organization that has contributed most to strategic thinking on climate change, and its implications for maritime strategy, policy and plans. The US Navy’s Climate Change Roadmap identifies conditions of particular naval interest, including sea level rise, the frequency and intensity of tropical storms, rainfall patterns and concentrations of GHGs. These conditions in US Navy areas of influence could translate into greater demands for certain types of naval tasks such as maritime security, humanitarian assistance and disaster relief, defence support of civil authorities, maritime domain awareness, search and rescue, and strategic sealift. He reviews the types of seaborne and airborne assets that will be needed to tackle these tasks. Thirdly, he discusses the internal challenges confronted by maritime security forces in reducing GHG emissions from their ships and other vehicles, and in 
attaining greater energy efficiency. Finally he suggests that the overall impact of climate change on maritime security forces is likely to be gradual rather than abrupt, leaving time for maritime security forces to invest in basic scientific research and marine environmental assessment, the development of new technological solutions to emissions reductions and better national and regional security risk assessments.

Chapter 9 by Stathis Palassis considers the broad problem of reducing GHG emissions from the burgeoning international shipping sector. The IPCC Fourth Assessment Report: Climate Change 2007 estimated the contribution of international shipping to global GHG emissions in 2007 at 2.7 per cent. Palassis reviews the international legal framework for the reduction of GHG emissions, and the prevention, reduction and control of vessel source pollution, exploring how these two areas of international regulation have become interlinked. He discusses the first steps towards regulating atmospheric pollution from international shipping by the IMO through Annex VI to MARPOL 73/78, and the ambit of pollutants covered by these measures. He then traces the IMO’s continuing efforts to reduce GHG emissions from international shipping through a combination of technical, operational and market-based measures. In particular, he canvasses the debates that have emerged in the IMO between developing and developed States over their relative responsibilities to reduce the GHG emissions of their shipping fleets. He views the essence of the debate revolving around the role of developing States in reducing their GHG emissions as their strong reliance on applying the principle of common but differentiated responsibility and their questioning of the appropriateness of applying uniform international standards, which they see as economically disadvantageous. Developing States have also challenged the appropriateness of the IMO as a competent international organization and questioned whether amending Annex VI of MARPOL 73/78 to include GHG emissions is the correct regulatory strategy, identifying the UNFCCC and its COP mechanism as the more appropriate forum to discuss 
these issues. On the other side of the debate, Palassis explains that developed States view the IMO as the competent international organization within which to promulgate rules for the reduction of GHG emissions through the adoption of uniform standards under Annex VI of MARPOL 73/78. He tracks progress by the IMO in the introduction of energy efficiency measures for the international shipping sector, and discusses the complex legal and political challenges involved in introducing market-based measures designed to reduce GHG emissions from this growing transport sector.

Finally, in Chapter 10, Rosemary Rayfuse and Robin Warner examine the regulatory frameworks emerging for a range of $\mathrm{CO}_{2}$ sequestration methods that either involve the oceans or affect the marine environment. They explain that considerable financial and technological investment has already been made in offshore carbon capture and storage (OCCS), which seeks to capture $\mathrm{CO}_{2}$ from point sources of emissions and sequester it in sub-seabed geological formations. Other methods seek to boost the capacity of the oceans to capture and absorb atmospheric $\mathrm{CO}_{2}$ either by depositing substances or wastes into the sea or depositing structures or devices into the ocean to increase the production of organic material in the surface ocean, thereby promoting increased draw down of photosynthesized carbon to the deep ocean. Both OCCS and marine geo-engineering schemes have the potential for yet unknown and possibly adverse effects on the marine environment. The chapter focuses on the legal challenges posed by these schemes, in particular ocean fertilization, and the progress that has been made in regulating these activities at global and national levels. It describes these processes, their objectives and their potential impacts on the marine environment. It discusses the applicability of existing international law principles to these processes and the regulatory gaps and ambiguities that exist. The emerging policy and regulatory framework for these processes at the global and national level in Australia is examined. Finally, Rayfuse and Warner conclude that the relatively advanced and permissive regulatory position 
developed for OCCS represents a significant contrast to the embryonic and decidedly cautious regulatory situation emerging for other marine geo-engineering methods designed to capture $\mathrm{CO}_{2}$.

$<\mathrm{a}>7$. INNOVATIVE AND MULTILATERAL SOLUTIONS

Climate change poses a complex mix of threats to the environmental integrity and security of the marine and coastal areas of the Asia-Pacific region. Combating these threats will demand innovative and multilateral solutions from regional States in cooperation with relevant regional and global organizations. Some of this cooperation is already occurring, but will require extension and ongoing development to reverse some of the adverse impacts of climate change on the biodiversity and security of the region. This book examines some of the collaborative mechanisms that could be implemented among States and regional organizations to alleviate some of the worst effects of climate change on marine biodiversity and maritime security in the Asia-Pacific region, and considers progress towards achieving these mechanisms. These include joint development and conservation arrangements for fisheries and the introduction of transboundary marine environmental protection measures such as marine protected areas and transboundary environmental impact assessment of proposed activities and projects. Efforts are also under way within the region towards the settlement or at least management of contentious maritime disputes, as evidenced by the maritime joint zones and arrangements alluded to above. Multilateral mechanisms for hydrocarbon exploitation and ocean energy development could avert future energy supply downturns. The establishment of further cooperative maritime surveillance and enforcement arrangements among States in the Asia-Pacific region may also assist in combating the increase in transnational criminal activity at sea. Enhanced criminal justice cooperation 
relationships among States in the region would complement these cooperative law enforcement efforts at sea. Cooperative resettlement arrangements between regional and extra-regional States for populations displaced by sea level rise or natural disaster will also be an important component of any plan to tackle the adverse security implications of climate change.

The negative impacts of climate change, combined with the other regional insecurity factors already outlined, are highly likely to provoke more competition for declining marine resources such as fish and untapped marine resources such as offshore hydrocarbons. There is already ample evidence of tension and active confrontation among some South East Asian States, for example over access to the hydrocarbon resources speculated to lie under the South China Sea. This ‘oil factor’ can also be seen as a driver in Indonesia and Malaysia’s tensions over overlapping maritime claims - something not unconnected to control over the so-called 'Ambalat block', a potentially hydrocarbons-rich area of seabed in the Celebes Sea off eastern Borneo. These simmering disputes highlight the urgency of negotiating creative solutions to maritime disputes to enable equitable access to and distribution of available offshore resources. Many analysts have suggested that joint development arrangements be negotiated to facilitate exploitation of the hydrocarbon resources of the South China Sea, with the resolution of territorial sovereignty claims deferred to accommodate such exploitation. There are some models for this type of arrangement, such as the 2002 Timor Sea Treaty and the 2006 Certain Maritime Arrangements Treaty between Australia and Timor L’Este, although the number of claimants to the Spratly Islands amplifies the challenges involved in achieving an agreement acceptable to all parties. Consequently, as attractive as joint development for the South China Sea appears on paper, unfortunately this does not appear to be a likely outcome in the near term, though this does not eliminate the possibility of gradual, incremental progress to resolve or at least manage disputes (Schofield et al. 2011). 
In the fisheries sphere such positive developments are illustrated by the fact that there are already some joint conservation and management arrangements in the South China Sea and South East Asia, and these practical joint endeavours may assist in preventing potential disputes among regional States over declining fish stocks and in adapting to the changes in fish stocks that could occur due to climate change. For instance, China and Vietnam negotiated two agreements to conserve, manage and exploit the fisheries resources of Beibu Gulf: the 2000 Agreement between the Government of the People’s Republic of China and the Socialist Republic of Vietnam on Fishery Cooperation in Beibu Gulf and a 2004 protocol to the earlier agreement. The agreements are administered by a Joint Fishery Committee with members from both parties. Three zones are designated: the Common Fisheries Zone, the waters in transitional arrangements, and the buffer zone for small sized fishing boats. The Common Fisheries Zone covers $33500 \mathrm{~km}^{2}$ - 27.9 per cent of the gulf's total area. The parties are committed to undertaking long-term fisheries cooperation in this area over the 12year term of the agreement, with a further three-year extension envisaged in Article 22 of the 2000 agreement, which involves joint development of conservation and management measures to conserve, manage and sustainably exploit the living resources of the zone. The number of vessels with access to the zone is determined annually, taking into account allowable catches established on the basis of joint regular surveys of fishery resources, the impact on respective fishing activities of both parties, and the need for sustainable development of the resources while respecting the principle of equality and mutual benefit. The waters in transitional arrangements zone was established as an interim measure to limit the number of fishing vessels of each party that could access certain areas of their respective exclusive economic zones for four years after the 2000 agreement entered into force. The buffer zone for small sized fishing boats (no longer than $15 \mathrm{~m}$ or with engines of no more than 60 horsepower) was established to avoid disputes caused by the inadvertent illegal entry 
of small sized fishing boats of one party into the territorial sea of another. Under the agreement if either party finds small sized fishing boats of the other party in its buffer zone waters, it may warn the boats to leave or take necessary measures to repel them from the area without using force or detention and arrest. Cooperative arrangements of this type, including those mentioned in the Gulf of Thailand with respect to seabed oil and gas and in the East China Sea in relation to fisheries, are potentially critical lynchpins in mitigating the extra burden created by climate change effects among States in the Asia Pacific region.

\section{$<\mathrm{a}>8$. CONCLUSIONS}

While climate change may not be the only catalyst for marine biodiversity loss and regional insecurity in the Asia-Pacific region, it has a compounding effect on other causes of these problems. Climate change represents a potent exacerbating factor of other biodiversity loss and regional insecurity drivers such as overfishing, destructive fishing practices, poverty, fragile social circumstances and existing transnational crime networks. Similarly, the impacts of climate change on maritime jurisdictional issues threaten to complicate multiple already highly contentious and involved regional maritime disputes featuring broad areas of overlapping and conflicting maritime claims. If climate change adaptation measures are not rigorously implemented the adverse effects of warming temperatures and ocean acidity on fish stocks, combined with overfishing and destructive fishing practices, could lead to the collapse of some fish stocks in the region, precipitating a food security crisis. Reinforcing the regional measures already in place to combat transnational crimes such as people smuggling and illegal fishing will be important in reducing the vulnerability of coastal populations displaced and marginalized by sea-level rise and severe weather events associated with climate change. Re-examining the maritime boundary and resource-related disputes that exist 
in the Asia-Pacific region to establish whether creative solutions can be found to maximize the benefits for all interested stakeholders can only assist the region in addressing the resource shortages that climate change and other factors will inevitably bring. Some coping mechanisms and multilateral initiatives are already in place to address these developments. However the adverse portents of climate change documented by the IPCC and other international bodies suggest that collaborative initiatives to mitigate its negative effects on marine biodiversity and food and human security need to be strengthened at all levels.

$<\mathrm{a}>$ REFERENCES

Abbott, Chris (2008), An Uncertain Future: Law Enforcement, National Security and Climate Change, Madrid, Spain: Fundacion para las Relaciones Internacionales y el Dialogo Exterior, available at: http://www.fride.org/download/COM_Law_Security_Climate_EN_feb08.pdf (accessed 22 April 2012).

Allison, Edward H., Allison L. Perry, Marie-Caroline Badjeck, W. Neil Adger, Katrina Brown, Declan Conway, Ashley S. Halls, Graham M. Pilling, John D. Reynolds, Neil L. Andrew and Nicholas K. Dulvy (2009), 'Vulnerability of national economies to the impacts of climate change on fisheries', Fish and Fisheries 10 (2), 173-196.

Barnett, Jon and W. Neil Adger (2007), 'Climate change, human security and violent conflict', Political Geography, 26 (6), 643-655.

Bradford, John F. (2005), 'The growing prospects for maritime security cooperation in Southeast Asia', Naval War College Review, 58 (3), 63-86.

Caron, David D. (1990), 'When law makes climate change worse: rethinking the law of baselines in light of a rising sea level', Ecology Law Quarterly, 17 (1990), 621-653. 
CENTRA Technology, Inc. and Scitor Corporation (2010), Southeast Asia: the Impact of Climate Change to 2030: Geopolitical Implications, Conference Report CR 2010-02, January, US National Intelligence Council, available at: http://www.dni.gov/nic/PDF_GIF_otherprod/climate_change/cr201002_southeast_asi a_pacific_islands_climate_change.pdf (accessed 22 April 2012).

Doyle, Thomas W., Richard H. Day and Thomas C. Michot (2010), Development of Sea Level Rise Scenarios for Climate Change Assessments of the Mekong Delta, Vietnam, Reston, Virginia: U.S. Geological Survey Open-File Report 2010-1165.

Dupont, Alan (2008), 'The strategic implications of climate change', Survival: Global Politics and Strategy, 50 (3), 29-54.

Food and Agriculture Organization (FAO) (2008), Report of the FAO Expert Workshop on Climate Change Implications for Fisheries and Aquaculture, FAO Fisheries Report No. 870, April, Rome, Italy: FAO, available at: ftp://ftp.fao.org/docrep/fao/010/i0203e/i0203e00.pdf (accessed 22 April 2012). Freestone, David (1990), 'International law and sea level rise’, in Robin Churchill and David Freestone (eds), International Law and Global Climate Change, London, UK and Dordrecht, The Netherlands: Graham and Trotman/Martinus Nijhoff. IPCC (2007), Contribution of Working Group II to the Fourth Assessment Report of the Intergovernmental Panel on Climate Change, 2007, New York, NY, USA: Cambridge University Press, available at: http://www.ipcc.ch/publications_and_data/publications_ipcc_fourth_assessment_repo rt_wg2_report_impacts_adaptation_and_vulnerability.htm (accessed 22 April 2012). Jasparro, Christopher and Jonathan Taylor (2008), 'Climate change and regional vulnerability to transnational security threats in Southeast Asia’, Geopolitics, 13 (2), 232-256. 
Mekong River Commission (MRC) (2010), Reducing the Impact of Climate Change on the Mekong Basin: the MRC's Climate Change and Adaptation Initiative, MRC Technical Paper No. 34, December, Phnom Penh, Cambodia: MRC, available at: http://www.mrcmekong.org/about-the-mrc/programmes/climate-change-andadaptation-initiative/ (accessed 22 April 2012).

Paskal, Cleo (2007), How Climate Change is Pushing the Boundaries of Security and Foreign Policy, Chatham House Briefing Paper, June, London, UK: Chatham House, available at: http://www.chathamhouse.org/sites/default/files/public/Research/Energy,\%20Environ ment\%20and\%20Development/bp0607climatecp.pdf (accessed 22 April 2012).

Prescott, Victor and Clive H. Schofield (2005), The Maritime Political Boundaries of the World, Leiden, The Netherlands and Boston, MA, USA: Martinus Nijhoff Publishers. Schofield, Clive H. (2009), 'Shifting limits? Sea level rise and options to secure maritime jurisdictional claims’, Carbon and Climate Law Review, 3 (4), 405-416.

Schofield, Clive H., Ian Townsend-Gault, Hasjim Djalal, Ian Storey, Meredith Miller and Tim Cook (2011) From Disputed Waters to Seas of Opportunity: Overcoming Barriers to Maritime Cooperation in East and Southeast Asia, National Bureau of Asian Research Special Report No.30, July 2011.

Shepherd, John et al. (2009) Geo-engineering the Climate: Science, Governance and Uncertainty, London: Royal Society.

Smith, Paul J. (2007), ‘Climate change, mass migration and the military response’, Orbis, 51 (4), 618-619.

Willis, B.L., S. Dove, O. Hoegh-Guldberg, J.M. Lough, M. McCulloch, P.L. Munday, M.S. Pratchett, R. Salm and M.J.H. van Oppen (2008), 'Climate change threats to the Coral Triangle’, Draft Background Paper, Version 2, Coral Triangle Initiative Townsville 
Workshop November, available at:

http://www.coralcoe.org.au/events/ctiworkshop/papers/8\%20Climate\%20Change.doc (accessed 22 April 2012).

WorldFish Center (2006), The Threat to Fisheries and Aquaculture from Climate Change, Policy Brief, Penang, Malaysia: WorldFish Center, available at: www.worldfishcenter.org/resource_centre/ClimateChange2.pdf (accessed 22 April 2012). 